\title{
Development of Curriculum and Learning System in Pondok Pesantren. (A Case Study at Pesantren Al Falah Dago Bandung)
}

DOI: https://doi.org/10.47175/rielsj.v2i1.196

\section{| Koko Adya Winata ${ }^{1}$ | Andewi Suhartini ${ }^{2}$ | Nurwadjah Ahmad ${ }^{3}$ |}

\author{
1,2,3 Sunan Gunung Djati State \\ Islamic University, Bandung \\ 1adyawinta@gmail.com, \\ 2andewi.suhartini@uinsgd.ac.id, \\ ${ }^{3}$ mnurwadjah.ahmad@gmail.com
}

\begin{abstract}
This study aims to determine the development of the curriculum and learning system implemented in the Al Falah Dago Islamic boarding school in Bandung. This research uses a qualitative approach in the form of a case study. Data were collected using observation, interview, field observation, and document study. The validity of the data was obtained utilizing triangulation and supplemented with referential adequacy. Data analysis was performed by data reduction, data presentation, and verification. The results of the research show that; 1) Pondok Pesantren Al Falah Dago, Bandung City still maintains the old pattern both in terms of curriculum and learning system, 2) learning activities are carried out using yellow books or classical books, 3) the learning system uses traditional methods such as sorogan, bandongan, memorization and bahsu al-Masa'il, as well as memorizing and modern uses such as group learning and discussions between students.

KEYWORDS

Development Curriculum; Learning System; Islamic Boarding School
\end{abstract}

\section{INTRODUCTION}

Pesantren is not only an Islamic education institution that teaches its students the sciences related to Islamic teachings, good faith, morals, muamalah, and muasyarah. Pesantren are also Islamic educational institutions that teach independence, togetherness, simplicity, and sincerity. Therefore, pesantren is believed to be one of the agents of social change that has given birth to positive ideas that are very useful for people's lives. On the way, the pesantren was not trapped and struggled from book to book. Pesantren is no longer a place for a sich's education. Many Islamic boarding schools perform social roles with all their adaptation patterns. Even in the pre-independence era of Indonesia, pesantren also played an important role in the fields of politics, security, and national defense (Marlina, 2014). The potential of pesantren can also be seen from the learning model, learning curriculum, and learning materials applied in different pesantren other educational institutions. This has given rise to a lot of potential for pesantren, both educational and non-educational. Another potential that exists in pesantren is the strong culture of the pesantren which places the kyai as a very centralized leader. The students will imitate every movement of the kyainya and have a strong loyalty to the dawuh or his kyai policies, this is the main factor in implementing the values of the pesantren.

The important role of Islamic boarding schools in Indonesia in carrying out the transmission of religious knowledge is very dominant because, in the history of Indonesian development, it was noted that pesantren grew and developed in line with and in line with the history of the nation's development. Pesantren cannot be generalized to one another, 
because they have features or similarities and differences from each other so that some pesantren observers assume that in their development several classifications include: Salafi Islamic Boarding Schools. Salafi Islamic boarding schools are Islamic boarding schools that teach their students to learn Islam specifically without including general education in it. The activities carried out are usually studying the religious sciences by using yellow books or ancient (classical) books, using traditional methods such as memorization, translating books during the teaching and learning process. Khalafi Islamic Boarding School. The Klalafi Islamic boarding school is a pesantren that implements a classical teaching system (madrasah), provides general knowledge and religious knowledge, and also provides skills education. Meanwhile, the meaning of khalafiyah (modern) pesantren is pesantren that adopts the madrasah or school system that includes general subjects in the developed madrasah curriculum or pesantren which organizes types of public schools such as; MI / SD, MTs / SMP, MA / SMA / SMK and even universities in their environment. Integrated Islamic Boarding School. Integrated Pesantren is a pesantren that places more emphasis on vocational or vocational education, as is the work training center in the Ministry of Manpower, with an integrated program. While the majority of students come from school dropouts or job seekers.

Pesantren Al Falah Dago, Bandung City already has a learning system that is applied through classical and modern models. The classic model still uses yellow books with the sorogan, bandongan, and memorization methods. The modern learning model provides opportunities for students by using a contextual-based and group learning system. The learning system developed at the Al Falah Dago boarding school in the city Bandung combines traditional and modern methods. The students not only follow the sorogan, clown, and rote methods but also learn through group study, discussion, and problem solutions. So that student is expected to have a comprehensive understanding of various disciplines that will lead them to become superior students.

\section{RESEARCH METHODS}

This study uses a qualitative approach, with data collection techniques through documentation study, observation, interviews. Sources of interviews were conducted with clerics, religious teachers, pesantren staff, and students. While data analysis is done by compiling, connecting, reducing, analyzing, presenting, and concluding. Testing the validity of the data includes credibility, transferability, dependability, and confirmability. So that this research can provide accurate and valid information concerning curriculum development and learning systems at the Al Falah Dago Islamic boarding school, Bandung.

\section{RESULTS AND DISCUSSION}

\section{Overview of Al Falah Dago Islamic Boarding School}

The Al Falah Dago Islamic Boarding School was founded in stages in 1950 by KH Saefudin Ahmad (late) who is better known as ustadz Idi. He is the founder of Al Falah Dago Islamic boarding school which has high enthusiasm and integrity towards Islamic education. Since the colonial government, Ustadz Idi has been very active in preaching Islamic values so that he often goes out of jail for opposing colonialism. His persistence in preaching Islam gave birth to an idea to establish a madrasa or place of prayer where the process of transforming Islamic religious values can be carried out. The existence of madrasas has attracted local residents to participate in the religious learning process carried out by Ustadz Idi. With the consideration of many people participating in the recitation, a mosque was built as a means of carrying out congregational prayers as well as the right step in practicing Islamic values. 
Pesantern Al Falah Dago is a salafi-khalafi pesantren, a boarding school that teaches the yellow book and general education. The yellow books taught at the Al Falah Dago pesantren include; Kitab Safinah, Jurumiyyah, Khulashah, Imriti, Tijan, Sulam Taufik, kailani, Ta'lim Muta'alim, Irasyadul 'Ibad, Sofwatut Tafsir, Taqrib, Mukhtaral Hadith, and Fathul Mu'in. The learning process is carried out through the application of a learning material syllabus that is adjusted to the levels of education of the students. With a combination of the general learning system and the yellow book, it is hoped that students will have superior abilities in the fields of general science and religious knowledge to face life in society.

\section{Development of the Al Falah Dago Islamic Boarding School Curriculum}

The term curriculum comes from the Latin "curriculum". It originally meant "a running course, or a racecourse, especially a chariot racecourse." From this understanding, the curriculum is a "competition arena" where learning "competes" to master a lesson to achieve a "finish line" in the form of a diploma, diploma or degree. to achieve goals. The curriculum is the entire program, facilities, and activities of an educational or training institution to realize its vision, mission, and institution. Therefore, the implementation of the curriculum to support the success of an educational institution must be supported by the following: (Syamsul Bahri, 2011)

1. There are competent personnel.

2. There are adequate facilities.

3. The existence of supporting facilities as support.

4. The existence of educational support staff such as administrative staff, advisors, librarians, laboratories.

5. The existence of adequate funds, sixth,

6. The existence of good management.

7. Maintaining a supportive culture; religious, moral, national and others,

8. Visionary leadership is transparent and accountable

The variables above are requirements that must be met by every educational institution including pesantren in developing a curriculum to face the demands of society and the times. Pesantren Al Falah dago Bandung has been developing by taking into account the various needs of the pesantren both from human resources, infrastructure, and effective management. The development of the pesantren curriculum basically cannot be separated from the vision of national development which seeks to save and improve national life. Conceptually, Islamic boarding schools are optimistic that they will be able to meet the demands of the times. But keep in mind that the curriculum is only a guideline for the basic framework for the implementation of conceptual learning, including in the Salafi Islamic Boarding School, Therefore, the curriculum and Learning System for the Salafi Islamic Boarding School, one of the sub-systems of the boarding school, the development process must not conflict with the framework for administering the Islamic boarding school which is known to be distinctive, both in terms of the content and approach used. In general, the pesantren curriculum design used to serve students can be developed through; (Kholis Thohir, 2017).

1. Conduct a needs assessment to obtain the determinants of the curriculum and its background

2. Determine the subjects to be taught according to the needs and scope of the sequence.

3. Formulate the expected goals,

4. Determine the standard of expected learning outcomes so that the output can be measured, 
5. Determine which books are used as guidelines for teaching materials and are determined according to the order of the group level,

6. Determine the conditions that must be mastered by students to take lessons at the group level,

7. Determine a suitable learning strategy and provide various resources in the learning process,

8. Determine the evaluation tools for the assessment of learning outcomes, and

9. Draft an overall curriculum assessment plan and a sustainable development strategy.

Therefore, the order of the books is arranged as a guide for religious teachers and students in the learning process at the Al Falah Dago Islamic boarding school. The books taught to students are adjusted to the level of education and the students' understanding of the books being taught. The yellow books taught at the Al Falah Dago pesantren include: 1) Akhlaqul Banin, 2) Hadith Arbain, 3) Hadith Bulugul Maram, 4), Nahu Shorof (Jeremiah, Kaelani etc.), 5) Ushul Fiqih, 6) Fiqh, 7) Taqrib, 8) Fathul Majid, 9) Riyadushalihin, 10) Mukhtaral hadith, 11) Mustalahul Hadith, 12) Tijan, 13) Kifayatul Akhyar, 14) Tafsir Jalalain, 15) Khulashah, 16) Minhajul Muslim. By understanding the structure of the program, the Al Falah Dago Islamic Boarding School in Bandung is a religious education institution that prepares its students to have religious knowledge through systematic learning of the yellow book.

The curriculum development carried out by the Al Falah Dago Bandung Islamic boarding school can be seen from the opportunity for students to study general sciences through the classroom learning system. The students are taught academic knowledge, personality, and skills through a learning system that refers to the national curriculum. The curriculum development carried out by the Al Falah dago Bandung pesantren is intended so that students not only master religious disciplines but can master general knowledge and skills. This can be seen from the consistency of pesantren by developing education through school institutions starting from Al Falah Elementary School, Al Falah Middle School, Al Falah High School, and Al Falah Vocational High School. The pesantren's commitment to preparing superior santri is carried out through the development of the pesantren curriculum, namely by adding general subject matter and skills. General principles in curriculum development, namely: principles of relevance, flexibility, continuity, practicality/efficiency, and effectiveness. The principle of relevance, including internal and external relevance. Internally, it concerns the relevance that occurs between curriculum components (objectives, content/materials, strategy, and evaluation). While externally, it concerns the relevance of curriculum components to the demands, needs, and development of society (Purawadhi, 2019).

\section{Learning System in Al Falah Dago Islamic Boarding School Traditional Learning Methods}

Pesantren is a socio-religious institution that is a means of education for Muslims who want to learn more about religious sciences. In general, Islamic boarding schools have all the same characteristics, namely, the institution is led and cared for by a kyai in a complex that is characterized by namely the presence of a mosque or surau as a learning center, the santri dormitory as a residence for the students (students), beside the kyai's residence., with the "yellow book" as a handbook. According to Mustofa Bisri, in addition to these physical characteristics, there are still other characteristics that symbolize the character of the pesantren itself, namely the independence and obedience of students (students) to kyai who are often accused of being cult.). The traditional learning system is usually carried out in the 
salafiyah pesantren (traditional), with the main characteristic of teaching the yellow books. Learning classical Islamic books or we call them "yellow books", because of the characteristic of the book, the paper is yellow, especially the works of scholars who adhere to syafi'iyah ideology. All of this is indeed formal learning given in a traditional pesantren environment (Zamakhsyari Dhofir, 1994) Whereas the main feature of this traditional Islamic boarding school (salafiyah) recitation is to convey its learning by focusing on capturing harfiyah from certain books (texts). The approach used is to complete the reading of the book (text), and then proceed with reading another book (text). The learning system is sorogan, which is given in recitation to students (students) who have properly mastered the recitation of the Koran. Likewise, the main method of the learning system in the salafiyah pesantren (traditional) is the bandongan system or often called the wetonan system.

Pesantren Al Falah Dago Bandung in its learning system uses the salaf method, namely through the learning process of bandongan and sorogan as well as other learning that can be done in salafiyah pesantren in general. The bandongan learning system is also called the learning method with halaqah which is etymologically a circle of santri (students), or with a group of santri (students) whom they study under the guidance of an ustadz. The students sit in a circle and hold the book that has been determined under the guidance of the ustadz. The learning system at the Salaf Islamic Boarding School includes several methods (1) Sorogan, (2) Wetonan or bandungan, (3) Halaqoh, (4) Memorization or tahfizh, (5) Hiwar or musyawarah, (6) Bahtsul Masa'il (Mudzakaroh), (7) Fathul Kutub, (8) Muqoronah and (9) Muhawarah / Muhadatsah (Mun'im, A., Zainul, \& Rafiq, 2010). This learning system certainly does not represent the whole of the existing learning methods in Islamic boarding schools, but the following method is a brief description of the various variations commonly used and applied, namely:

a. Sorongan

Sorogan, comes from the word sorog (Javanese) which means to offer because every student is holding his book in front of the kyai or his assistant, the assistant of the kyai. This sorogan system includes individual learning, where a student faces a teacher, and there is mutual interaction between the two. This sorogan system proved to be very effective as the first grade for a student who aspires to be a pious person. This system allows a teacher to supervise, assess, and guide the maximum ability of a student in mastering Arabic. In the sorogan method, students read the yellow book and give meaning, while the teacher listens while giving notes, comments, or guidance if needed. However, in this method, the dialogue between teachers and students has not or does not occur. This method is appropriate when given to students of the same age as elementary level (Ibtidaiyah) and intermediate level (tsanawiyah) where everything needs to be provided or provided.

\section{b. Wetonan or Bandungan}

Weton / bandungan, the term weton comes from the word wektu (bhs.Jawa) which means time, because the recitation is given at certain times, before and or after performing the fardhu prayer. This weton method is a classical method, where the students follow the lesson by sitting around the kyai explaining the lesson, the students listening to their respective books and making notes on them. The bandungan method is the way of delivery in which a teacher, kyai, or ustadz reads and explains the contents of the yellow book, while students, students, or students listen, give meaning, and receive. So teachers play an active role while students are passive. And this bandungan method can be useful when the number of students is large enough and the time available is relatively small, while the material presented is quite a lot. 


\section{c. Halaqah}

The Halaqah method, also known as the munazaharah system, is a class group of the Bandung system. Halaqah means a circle of students or a group of students who study under the guidance of a teacher or study together in one place. This system is a discussion to understand the contents of the book, not to question the possibility of right or wrong what the book teaches, but to understand what the book teaches. When viewed from an intellectual development point of view, this method is beneficial for students who are intelligent, diligent, and capable, and willing to sacrifice a large amount of time for this study. This method is intended as the presentation of learning material in a way that students or students discuss it together through an exchange of opinions on a particular topic or problem in the yellow book, while the teacher acts as a "moderator". The discussion method aims to make students or students active in learning so that critical, analytical, and logical thinking will grow and develop.

\section{d. Memorization or tahfizh}

Memorization is a method applied in Islamic boarding schools, generally used to memorize certain books, such as Alfiyah ibnu Malik, or also often used to memorize AlQur'an, both short letters and as a whole. This method is relevant enough to be used for children, elementary and intermediate levels. At that age, the memorization method should be reduced gradually, and it is more appropriate to use formulas and rules. In the rote method, the students are given the task of memorizing certain readings within a certain period. The memorization of the students is then "deposited" in front of the kyai or ustadz, periodically or incidentally depending on the previous instructions. Thus, the emphasis in this lesson is that students can pronounce or recite a set of learning materials smoothly without seeing or reading the text.

\section{e. Hiwar or deliberation}

The hiwar or deliberation method is almost the same as the common discussion method we are familiar with so far. The difference is that the hiwar method is carried out in the range of deepening or enriching the existing material in the students. The characteristic of this hiwar method, students and teachers are usually involved in a debate forum to solve problems that exist in the books that are currently being studied by the students.

\section{f. Bahtsul Masa'l (Mudzakaroh)}

The Mudakarah method or in other terms bahtsul Masa'il is a scientific meeting, which discusses diniyah issues, such as worship, aqidah, and religious issues in general. This method is not much different from the deliberation method. It's just the difference, in the mudzakarah method, the requirements are for kyai or high-level santri. g. Fathul Pole The Fathul Kutub method is usually implemented for senior santri who will complete their education at the Islamic boarding school. And this is an exercise in reading books (especially classical books), as a vehicle to test their abilities after studying. h. Mukoronah The mokoronah method is a method that focuses on comparative activities, both comparisons of material, understanding, methods, and comparison of books. This method eventually developed in comparison to religious teachings. For comparison of religious material that usually develops in the Islamic Boarding School (Ma'had Ali), the term Muqoronatul Adyan is known. Meanwhile, the comparison of understanding or flow is known as Mukoronatul madzahib (comparison of schools). 
g. Muhawarah or Muhadatsah

Muhawarah is an exercise in conversing using Arabic. This activity is usually required by the Islamic Boarding School to its students during their stay at the Islamic Boarding School. This conversation is both between fellow students or students with the ustadz, kyai at certain times. They are given a vocabulary of Arabic or English words to memorize little by little, after the students have mastered a lot of vocabulary, they are obliged to use them in daily conversation. And there are also many Islamic boarding schools in this muhawarah method that are not required every day, but only once or twice a week or at certain times.

\section{Modern Learning Systems}

The principles of modern education in pesantren emerged because the traditional learning system was unable to face the demands and needs of society. Pesantren that apply a modern learning system can be seen from the existence of public educational institutions in the pesantren that their students participate in. General knowledge and skills are taught in the pesantren so that students not only have the ability to read the yellow book but also have abilities in other academic fields. Modern Islamic boarding schools seek to combine the traditionality and modernity of education. Classical style formal teaching system (teaching in the classroom) and integrated curriculum are adopted with certain adjustments. The dichotomy of religious and general knowledge was also eliminated. These two fields of knowledge are both taught, but the proportion of religious education is more dominant (Abdul Tolib, 2015). Pesantren Al Falah Dago Bandung has implemented both traditional and modern learning systems. Each student learns the yellow book and general knowledge and skills according to their respective education levels.

The Islamic boarding school was founded initially to provide religious knowledge to the students so that they became tafaquh fiddin. In line with the demands and needs of society, pesantren is not only oriented towards the learning system of religious knowledge but adapts to the needs of modern society. Therefore, Islamic boarding school Al Falah Dago Bandung has developed a curriculum and learning system that is integrative and combines traditional and modern. Through the integration of the learning system, it is expected that the students will have proficiency in the field of religion and general disciplines and skills. The establishment of the Islamic boarding school at first was only prioritizing religious knowledge, but later along with the needs of the community and the development of education, the current boarding school is not only oriented around religious knowledge (tafaqquhu fiddin) but has become more widespread in quality improvement resources of students so that they can face life by the challenges of the times (Gatot Krisdiyanto, et al., 2019).

The curriculum of modern pesantren is more academic by developing a learning system that adopts the demands and needs of society. The curriculum that is used as a guide in the learning system is divided into several fields of study. Namely, first, Arabic, including, AlImla ', Al-Insya', Tamrin Al-Lughah, Al-Muthalla'ah, AlNahwu, Al-Sharf, Al-Balaghah, AlAdab's Date, and Al-Khatt AlArabi. , all of which is conveyed in Arabic. Second, Diratsah Islamiyah, which includes, Al-Qur'an, Al-Tajwid, Al-Tauhid, Al-Tafsir, Al-Hadith, Musthalah Al-Hadits, AlFiqh, Ushul Al-Fiqh, Al-Fara'id, Al-Date. -Islam. Third, English, including, Reading and Comprehension, Grammer, Composition, and Dictation. Fourth, Science includes numeracy and Mathematics, Fifth, Natural Sciences (IPA) and Social Sciences (IPS) (Muhammad Ismail, 2011). 


\section{CONCLUSION}

The learning system used at the Al Falah Dago Islamic boarding school in Bandung uses classical and modern methods. The classic model still uses yellow books with the sorogan, bandongan and memorization methods. The modern learning model provides opportunities for students by using a contextual-based and group learning system. The learning system developed at the Al Falah Dago Islamic boarding school in Bandung combines traditional and modern methods. The students not only follow the sorogan, clown, and rote methods but also learn through group study, discussion, and problem solutions. So that student are expected to have a comprehensive understanding of various disciplines that will lead them to become superior students. The curriculum is determined by the Kyai and the learning system used is (1) Sorogan, (2) Wetonan or bandungan, (3) Halaqah, (4) Hafalan or tahfizh, (5) Hiwar or musyawarah, (6) Bahtsul Masa'il (Mudzakaroh), (7) Fathul Kutub, (8) Muqoronah and (9) Muhawarah / Muhadatsah. The modern learning system is applied by the Al Falah Dago Bandung Islamic boarding school through a process of teaching and learning activities in the classroom. The students not only master the disciplines of religion but can master general knowledge and skills. This can be seen from the consistency of pesantren by developing education through school institutions starting from Al Falah Elementary School, Al Falah Middle School, Al Falah High School, and Al Falah Vocational High School. The pesantren's commitment to preparing superior santri is carried out through curriculum development and learning systems that integrate traditional and modern methods.

\section{REFERENCES}

Abdul Tolib, (2015), EDUCATION IN MODERN PESANTREN PONDOK, Journal Risaalah, Vol. 1, No. 1, December 2015, 60-66.

Government Regulation No. 19 of 2005 concerning National Education Standards, article Paragraph 13.10,11

Gatot Krisdiyanto, Muflikha, Elly Elvina Sahara, Choirul Mahfud. (2019), PESANTREN EDUCATION SYSTEM AND MODERNITY CHALLENGES, Tarbawi Journal: Journal of Education p-ISSN: 1858-1080 | e-ISSN: 2615-6547 Vol. 15, No. 01, July 2019, pp. 11-21.

Khalis Thohir. (2017). Curriculum and Learning System Pondok Analytica Islamica Vio January 6-June 2017, 1

Muhammad Ismail, (2011), Modern Islamic Boarding School Education System Case Study of Darussalam Gontor Ponorogo Modern Pesantren Education, Journal of At-Ta'dib, Vol. 6, No. 1, June 2011, 147-167.

Mun'im, A., Zainul, \& Rafiq. (2010). the Role of Islamic Boarding Schools in Education for all in the Globalization Era. 3

Observation, documentation at Pesantren al-Falah. 2020, 2, 12,14

Purwadhi, (2019), Curriculum Development in XXI Century Learning, MIMBAR PENDIDIKAN: Indonesian Journal for Educational Studies, Volume 4 (2), September 2019, 103-112.

Syamsul Bahri, (2011), DEVELOPMENT OF BASIC CURRICULUM AND OBJECTIVES, Futura Islamic Scientific Journal, Volume XI, No. 1, August 2011, 15-34.

S. Robert Zais. (1976), Curriculum Principles and Foundation, New York: Happer and Raw Publisher, 1976. 9

Zamakhsyari Dhofir. (1994), Pesantren Tradition: A Study on the Life View of the Kyai, Prints IV, Jakarta: LP3ES, 1994. 4,5,7,8 